\title{
ШАРИЛЖНЫ ТӨРЛИЙН ЗАРИМ УРГАМЛЫН IN VITRO ХАВДРЫН ЭСЭД ҮЗУУЛЭХ НӨЛӨӨ
}

\author{
Ж.Болдбаатар, П.Эрдэнэбаатар, Л.Хулан, Д.Номиун, Б.Номин Ц.Оюунсүрэн \\ ШУА-ийн Биологийн хүрээлэнгийн Молекул биологийн лаборатори \\ Цахим шуудан: boogoo506@yahoo.com
}

\section{Хураангуй}

Орчин үеийн хүн төрлөхтөний эрүүл мэндэд тулгамдаж буй асуудалуудын нэг нь төрөл бүрийн хорт хавдрын өвчлөл юм. Дэлхий нийтээр уг өвчний үүсэл, шалтгаан, эмчлэх боломжын талаар өргөн хүрээний судалгаа шинжилгээний ажлууд хийж байна. Эмчилгээнд хэдийгээр мэс засал, туяа, химийн эмчилгээ ашиглаж байгаа ч эдгээрээс илүҮ үр дүнтэй байж болох, хүний эрүүл мэндэд сөрөг нөлөө багатай, эсвэл сөрөг нөлөөгүй биологийн гаралтай эм бэлдмэл гарган авах хэрэгцээ, шаардлага байсаар байна. Өдгөө янз бүрийн ургамал, тэдгээрийн тодорхой нэгдлүүдийн хавдрын эсрэг идэвхийг тогтоосон судалгаа ихээхэн хийгдэж зарим нь патентлагдаж хэрэглээнд нэвтрээд байна. Ханд болон цэвэр нэгдлийн хавдрын эсрэг идэвхийг тогтоох судалгааны сонгодог загвар бол уг хавдрын эдээс гаргаж авсан эсийн өсгөвөрийн шугамуудыг ашиглах явдал юм.

Бид судалгаанд шарилж буюу Artemisia-ийн төрөлд хамаарах гурван зүйл ургамлыг ( Artemisia xerophytica Krasch, Artemisia lavandulaefolia DC, Artemisia intricata Franch ) хорт хавдрын эмчилгээнд ашиглах боломжийг судлах зорилгоор зүйл бүрээс тус бүр этанол, $70 \%$ метанол ханд гарган авч хорт хавдарын in vitro дахь эсийн өсгөвөрийн (PCC, MDCK) үйл ажиллагаанд хэрхэн нөлөөлж буйг илрүүлэх ажил хийв.

Судалгааны дүнд A.xerophytica, A.intricata 2 зүйл ургамлын этанол болон метанол ханд хавдрын MDCK, РСС эсийн хуваагдалд концентрациас хамааран саатуулах нөлөөтэй байв. A. lavandulaefolia ургамлын этанол болон метанол хандууд нь зөвхөн РСС эсийн хуваагдлыг концентрациас хамаарч саатуулах үйлчилгээтэй. Бүх ургамлын хандууд MDCK, РСС эсүүдийн шилжин ургах чадварыг саатуулж байсан хэдий ч хавдрын эсийн Bcl-2 генийн экспрессээс хамааралтай апоптозын процессыг өдөөхгүй байв. Энэ нь дээрх хандуудын эсийн хуваагдал, шилжин ургах чадварт үзүүлж буй сөрөг нөлөө нь апоптозын процессоос хамааралгүй болохыг харуулна.

\section{Түлхүүр үг: Artemisia, шарилж, хавдар}

\section{ОРШИЛ}

Дэлхий нийт, ялангуяа хөгжиж буй орны хүн амын дунд төрөл бүрийн хавдар ихсэх хандлагатай байгаа өнөө үед уг өвчний үүсэх шалтгааныг тогтоох, урьдчилан сэргийлэх, эмчлэх шинэ арга, ажиллагааг бий болгох асуудал эрүүл мэндийн, нийгмийн тулгамдсан асуудлуудын нэг болоод байна. Одоогоор хорт хавдрын шалтгаан, эмчилгээний асуудлыг бүрэн шийдээгүй бөгөөд мэс засал, хими, туяа эмчилгээг голлон хэрэглэж байгаа хэдий ч тэдгээр нь төдийлөн төгс үр нөлөө үзүүлэхгүй байгаa юм. Хавдрын эмчилгээнд байгалийн гаралтай, тэр дундаа ургамлын гаралтай эм бэлдмэл хэрэглэх сонирхол нэмэгдэж сүүлийн 15 жилийн туршид энэ талаар судалгаа шинжилгээний ажил эрчимтэй өрнөж, зохих үр дүнд хүрч, зарим патент хэрэглээнд нэвтрэх болов [1]. Дэлхийн эрүүл мэндийн байгууллагаас 
гаргасан хавдрын тайланд дурдсанаар 2008 онд 12,7 сая хүн шинээр хорт хавдартай хэмээн бүртгэгдэж 7,6 сая хүн уг өвчнөөр нас барсан байна [2]. АНУ-д 2012 онд $1,638,910$ шинэ тохиолдол бүртгэгдэж 577,190 хүн нас баржээ[3]. Манай улсад хавдар судлалын үндэсний төвийн гаргасан мэдээгээр 2011 онд 100000 хүн амд 163,8 тохиолдол бүртгэгдсэн бол нас барсан 117,4 байна [4].

Хүн төрөлхтөн эртнээс нааш ургамлыг бүхий л чиглэлээр амьдрал, аж ахуйдаa өргөнөөр хэрэглэж ирсэн уламжлалтай. Тэдгээрийн нэг нь эмийн ургамлыг төрөл бүрийн эмчилгээнд хэрэглэх явдал юм. Бид судалгаанд Artemisia төрөлд хамаарах манай орны байгаль цаг уурын өөр өөр бүсээс цуглуулсан 3 зүйл шарилж A.xerophytica Krasch, A.lavandulaefolia DC, A.intricata Franch сонгон авч ашиглав. Ar- temisia төрөлд 500 гаруй зүйл хамрагдах ба эдгээр нь өвөрмөц үнэртэй, гашуун амттай бөгөөд Ази, Европ, Хойд америкт тархсан байдаг[5]. Химийн нэгдлийн хувьд монотерпенүүд, сесквитерпенүүд, сесквитерпений лактонууд, флавоноидууд, кумаринууд, стеролууд, полиацетиленүүд агуулдаг учир шинжлэх ухаан үйлдвэрлэлд ашиглах боломж ихтэй юм[6]. Монгол оронд 97 зүйл шарилж ургадаг ба энэ нь дэлхийн нийт шарилжны $1 / 5$ нь юм [7]. Энэ төрлийн ургамлуудыг эртнээс эдүгээ хүртэл ардын эмнэлэг, анагаах ухаанд өргөн хүрээтэй хэрэглэсээр байна [8]. Жишээ нь Казакстаны эрдэмтэд гөлгөр шарилж A.glalella-аac “Арглабин” лактон гарган авч уушиг, элэг, хөхний булчирхай, өндгөвчний хавдрыг эмчлэх болсноор эдүүгээ 11 оронд патентлагдаж 6 оронд хэрэглэгдэж байна [9].

\section{СУДАЛГААНЫ МАТЕРИАЛ АРГА ЗУЙ}

Ургамлын цуглуулга, дээж бэлтгэх: Ургамлын дээжүүдийг 2011-2012 онуудад цуглуулсан. Artemisia xerophytica Krasch ургамлыг Өмнөговь аймгийн Ханбогд сумын нутаг Ундаан голын зүүн эргээс 2012 оны 9 сарын 12-ны өдөр түүсэн бөгөөд доктор Ж.Санжид тодорхойлсон. Artemisia intricata Franch ургамлыг Говь-Алтай аймгийн Цогт сумын нутаг Баянтоорой тосгоны орчмоос 2012 оны 10 сарын 14-ний өдөр түүж, ангилал зүйг доктор Ш.Дариймаа тодорхойлсон. Artemisia lavandulaefolia DC Дорнод аймгийн Халх гол сумын нутаг Хянганы нуруунаас 2011 оны 08 сарын 25-ний өдөр түүж, доктор Ч.Санчир , Ш.Дариймаа нар тодорхойлсон. Түүсэн ургамлуудыг сүүдэр газар хатааж даавуун уутанд хадгалсан.

Ургамлаас ханд гарган авах : Гурван зүйл хатаасан ургамлын газрын дээд хэсгийг хайчилж жижиглэсэн ба ургамал бүрээс 40 граммыг авч 2 хуваан 500 млийн колбонд хийсэн. Нэгийг нь 200 мл хүртэл 100\% этанол, хоёр дахийг нь $70 \%$ метанолд 14 хоног өрөөний температурт хандлав. Хандыг цаасан шүүлтүурээр шүүж вакуум ууршуулагчаар $40^{\circ} \mathrm{C}$-д минутанд 90 эргэх нөхцөлд нэрж хандыг хатааж татах шүүгээнд дахин 48 цаг байлгаж үлдэгдэл органик уусгагчийг ууршуулсан.

Эсийн үржэн олшролын судалгааг эсийн митохондрийн редуктаза ферментийн идэвхийг тодорхойлж тооцох (MTT assay) аргаар хийсэн. Эсийн митохондрийн редуктаза энзимийн идэвхийг тодорхойлоход уг энзимийн субстрат МТТ бодисыг ашиглав.

PCC ба MDCK эсийг ижил тоогоор 96 нүд бүхий хавтанд тарьж, 50 мкг/мл, 100 мкг/мл, 200 мкг/мл, 300 мкг/мл, 400 мкг/мл, 400 мкг/мл концентрацитай ханд бүхий тэжээлийн орчинд өсгөвөрлөв. Митохондрын редуктаза энзим нь МТТ субстратад үйлчилж түүнийг формазин болгон задалдаг учир эсийн өсгөвөрт МТТ нэмж 1 цагийн турш байлгасны дараа дээрх энзимийн үйлчлэлийн дүнд үүссэн уусамтгай формазины хэмжээг гэрэл шингээлтийн 550 нм-ийн утганд хэмжиж тодорхойлов[10]. 
Эсийн морфологид ҮзҮүлэх нөлөөг тогтоох шинжилгээ

Ижилтооныэсүүдийг 24цагөсгөвөрлөж 100 мкг/мл хандаар 48 цаг үйлчилсэний дараа зургийг нь авч хяналтын болон хандаар үйлчилсэн эсүүдийн морфологийн өөрчлөлтийг харьцуулавн үзэв [11].

Эсийн шилжин хөдлөх чадварын шинжилгээ Өсгөврийн аягануудад тодорхой тооны эсийг $37^{\circ} \mathrm{C}$-д эсийн нэг давхрага үүстэл өсгөвөрлөж эсийн гадаргуу дээр зохиомлоор шарх үүсгэж 1хPBS-ээр угаасны дараа хандтай тэжээлийн орчин хийж шархны анхны хэмжээ болон 24, 48, 72 цагийн дараах хэмжээний зургуудыг авч Tsview программ ашиглан авч хэмжилт хийсэн . Yр дүнг Microsoft Excel программ ашиглан боловсруулав [12].

\section{СУДАЛГААНЫ ҮР ДУН}

Эсийн үржэн олшролын шнжилгээний дүн

Нийт гурван ургамлын зургаан хандыг 50, 100, 200, 300, 400, 500 мкг/мл тус тус концентрациар хавдрын эсүүдэд үйлчилсэн. A.xerophytica A.intricata ургамлуудын этанол болон метанол хандууд MDCK эсийн хуваагдалд концентрациас хамаарсан саатуулах нөлөө үзүүлж байв. A.xerophytica, A.intricata ургамлуудын этанол хандууд бага (50 мкг/мл) концентрацитай үед хяналтын эсүүдтэй харьцуулахад 64,5\% ба 60,8\%иар саатуулах үйлчилгээ үзүүлсэн байна. Эдгээр хандууд магадгүй эс хордуулах үйлчилгээтэй байж болох юм. A. lavandulaefolia ургамлын этанол ба метанол хандууд саатуулах нөлөө үзүүлээгүй бөгөөд зарим концентраци эсийн хуваагдлыг дэмжсэн үр дүн үзүүлсэн (1-р зураг А). РСС эсэд хийсэн шинжилгээгээр гурван ургамлын 6 ханд бүгд концентрациас хамаарч эсийн хуваагдлыг саатуулах нөлөө үзүүлэв.
ДНХ-ийн фрагментацийн шинжилгээ: Ижил тооны эсийг 24 цагийн өсгөвөрлөсөний дараагаас 100 мкг/мл хандаар 48 цаг үйлчлэв. ДНХ ялгах цомог (Intron i-genomic) ашиглан туршилтын болон хяналтын эсүүдээс геномын ДНХийг ялгаж $0,8 \%$-ийн агарозын гельд электрофорез явуулав. Гелийн зурагт ДНХийн задрал үүссэн эсэхэд анализ хийв [13].

Генийн экспрессийн шинжилгээ (Gene expression assay): Хавдрын үед ихээхэн идэвхждэг хавдар дарангуйлагч ген болох Bcl-2 генийн экспрессийн судалгааг ургамлын хандаар үйлчилсэн болон үйлчлээгүй эсүүдээс ялгасан РНХ ашиглан RT-PCR-ийн аргаар хийв. GAPDH генийг эерэг хяналтаар авав [14].

Концентрацийг нэмэх тусам (50-500 мкг/ мл) 3-аас 84\% хүртэл эсийн хуваагдлыг саатуулж байна (1-p зураг Б). Ханд тус бүрийн эсүүдийн хуваагдлыг $50 \%$-аaр саатуулах концентрацийг тооцсон дүнг 1-p хүснэгтэд үзүүлэв.

\section{Эсийн шилжин ургах чадварын шинжилгээний дүн}

Гурван ургамлын зургаан хандаар үйлчилсэн эсүүдийн нэг давхаргад зохиомлоор шарх үүсгэж 24, 48, 72 цагуудад зураг аван хэмжилт хийж хандаар хяналтын эсүүдтэй харьцуулан шархыг нөхөх хурдыг тооцов. Бүх ханд хяналтын эсүүдтэй харьцуулахад 2,74\% -өөс 74,7\% MDCK болон РCC эсийн шилжин ургах чадварыг саатуулсан. Эдгээрээс гурван зүйл ургамлын этанол хандтай харьцуулан үзэхэд метанол хандууд MDCK эсийн шилжин ургах хурдад саатуулах үйлчилгээгээр илүҮ байв(3-р зураг). 

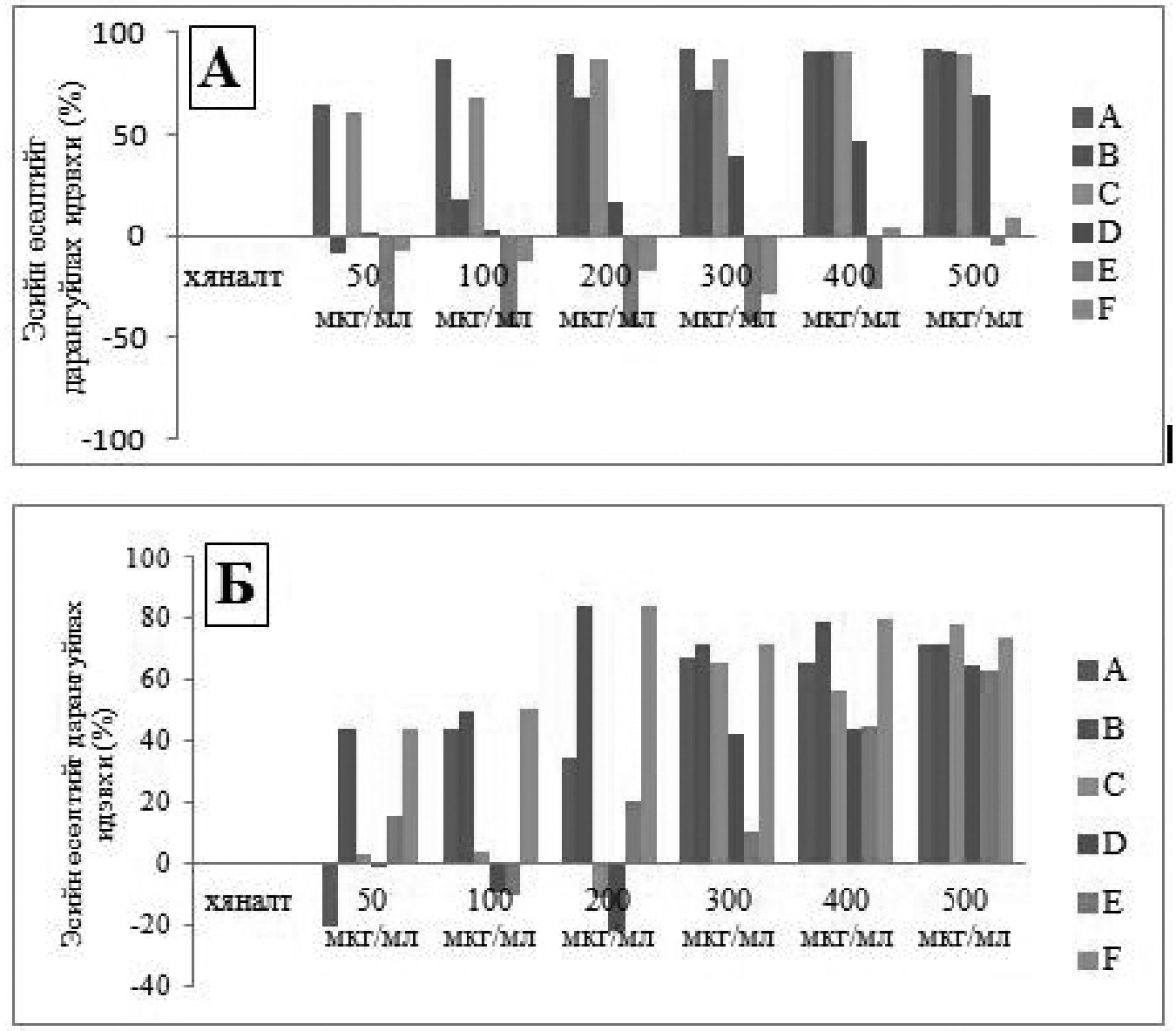

1-p зураг. МDCK (А) болон РСС (Б) эсийн хуваагдльг саатуулах нөлөө(\%). A- A.хегорhytica этанол ханд, B-A.хегорhytica 70\%-ийн метанол ханд, C-A.intricate этанол ханд, D-A.intricate 70\%-ийн метанол ханд, E-A.lavandulaefolia этанол ханд, F-A.lavandulaefolia метанол ханд.

Хүснэгт 1

Хавдрын эсүҮдийн хуваагдлыг 50\% саатуулах ханд тус бүрийн концентращийг тооисон дүн

\begin{tabular}{|l|c|c|}
\hline \multicolumn{1}{|c|}{ Ханд } & $\begin{array}{c}\text { МРСК эсийн хуваагдлыг өсгөвер } \\
\text { 50\% саатуулах (IC50) } \\
\text { концентраци (мкг/мл) }\end{array}$ & $\begin{array}{c}\text { РСС эсийн хуваагдлыг } \\
\text { 50\% саатуулах (IC50) } \\
\text { концентраци (мкг/мл) }\end{array}$ \\
\hline A.xerophytica этанол & 30.61 & 295.4 \\
\hline A.Xerophytica 70\%-ийн метанол & 232.9 & 552.6 \\
\hline A.Intricata этанол & 76.78 & 416.3 \\
\hline A.Intricata 70\%-ийн метанол & 313.6 & 33.4 \\
\hline A.Lavandulaefolia 70\%-ийн этанол & 4551 & 489.5 \\
\hline A.Lavandulaefolia метанол & 3765 & \\
\hline & & \\
\hline
\end{tabular}



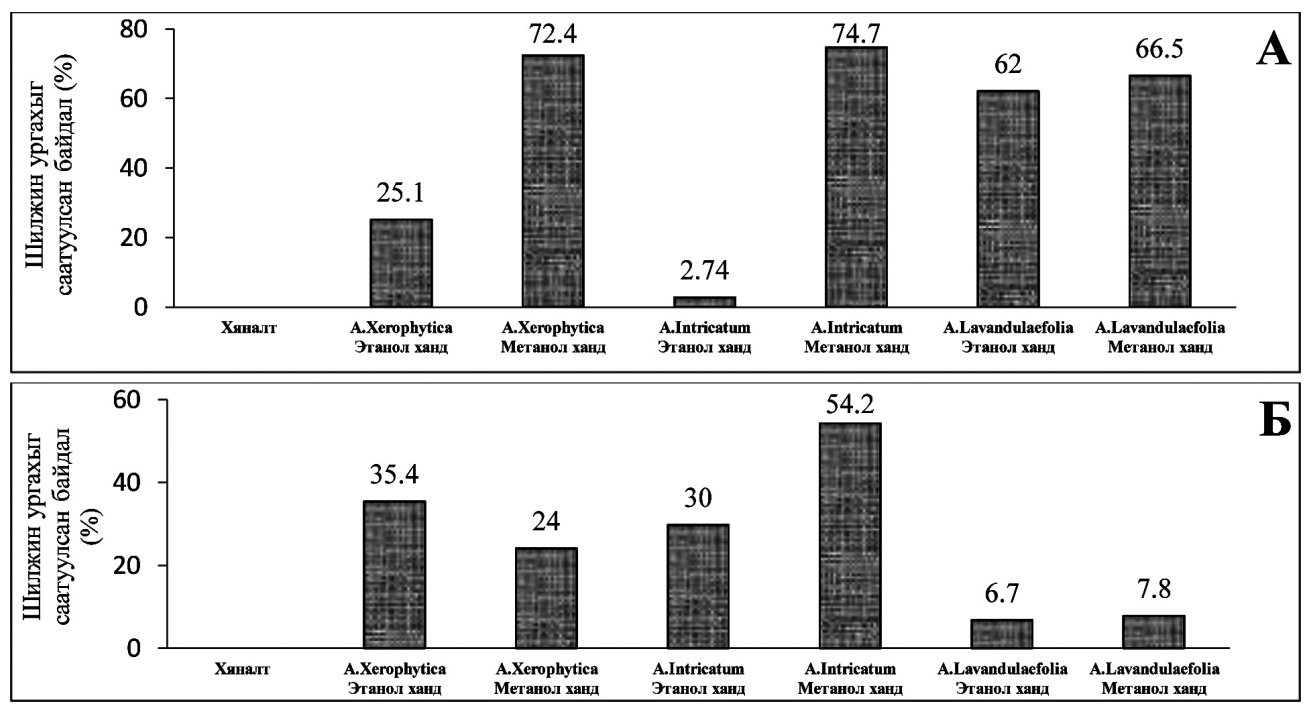

3-р зураг. Гурван зүйл ургамлын зургаан хандны MDCK (A) болон РСС (Б) эсийн шилжин ургах чадварыг саатуулах нөлөө (\%).

Эсийн морфологит ҮзҮҮлэх нөлөөг тогтоох шинжилгээний дүн

РСС эсийг 100 мкг/мл хандаар 48 цаг үйлчилсэний дараах морфологийн өөрчлөлтийг

үйлчлээгүй

эсүҮдтэй харьцуулан үзэв. Хандаар үйлчилсэн эсүүд хэвийн морфологоо алдаж гэмтэлд орж буй байдал ажиглагдсан (4-р зураг).

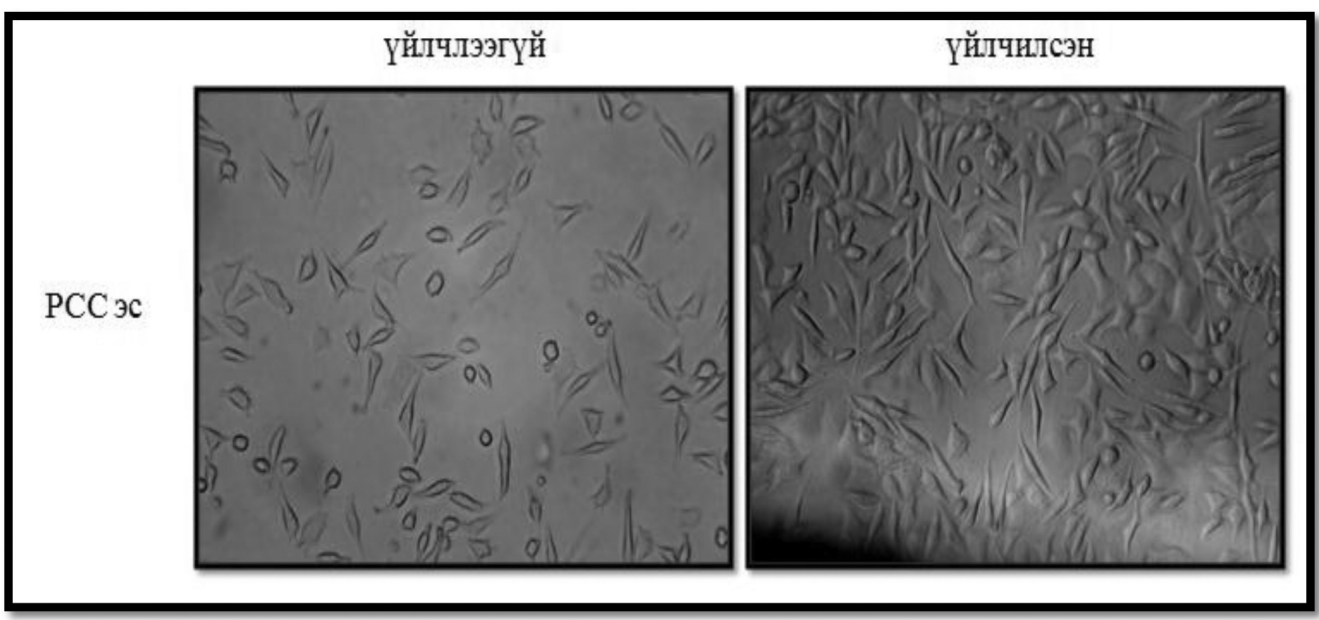

4-p зураг. 100 мкг/мл А.Хегорhytica ургамльн этанол хандаар үйлчилсэн болон үйлчлээгуй РСС эсүҮдийн 24 иагийн дараа харагдах байдал (өсгөлт 10 дахин).

ДНХ-ийн фрагментацийн шинжилгээний дүн

Апоптозийн процессын сүүлийн шатанд ургамлын апоптотик энзимүүд эсийн макромолекулуудыг жижиг хэсгүүд болгож задалдаг тул энэ нь ургамлын ханд хавдрын эсүүдийн апоптозын процессыг өдөөж буй эсэхийг харуулдаг шинжилгээ юм. Энэхүү шинжилгээний дүнд 6 төрлийн ургамлын 100 мкг/мл хандаар үйлчилсэн 
эсүүдээс ялгасан нийт ДНХ-ийг агарозын ажиглагдсангүй (5-р зураг). гельд гүйлгэхэд задрал үүссэн байдал

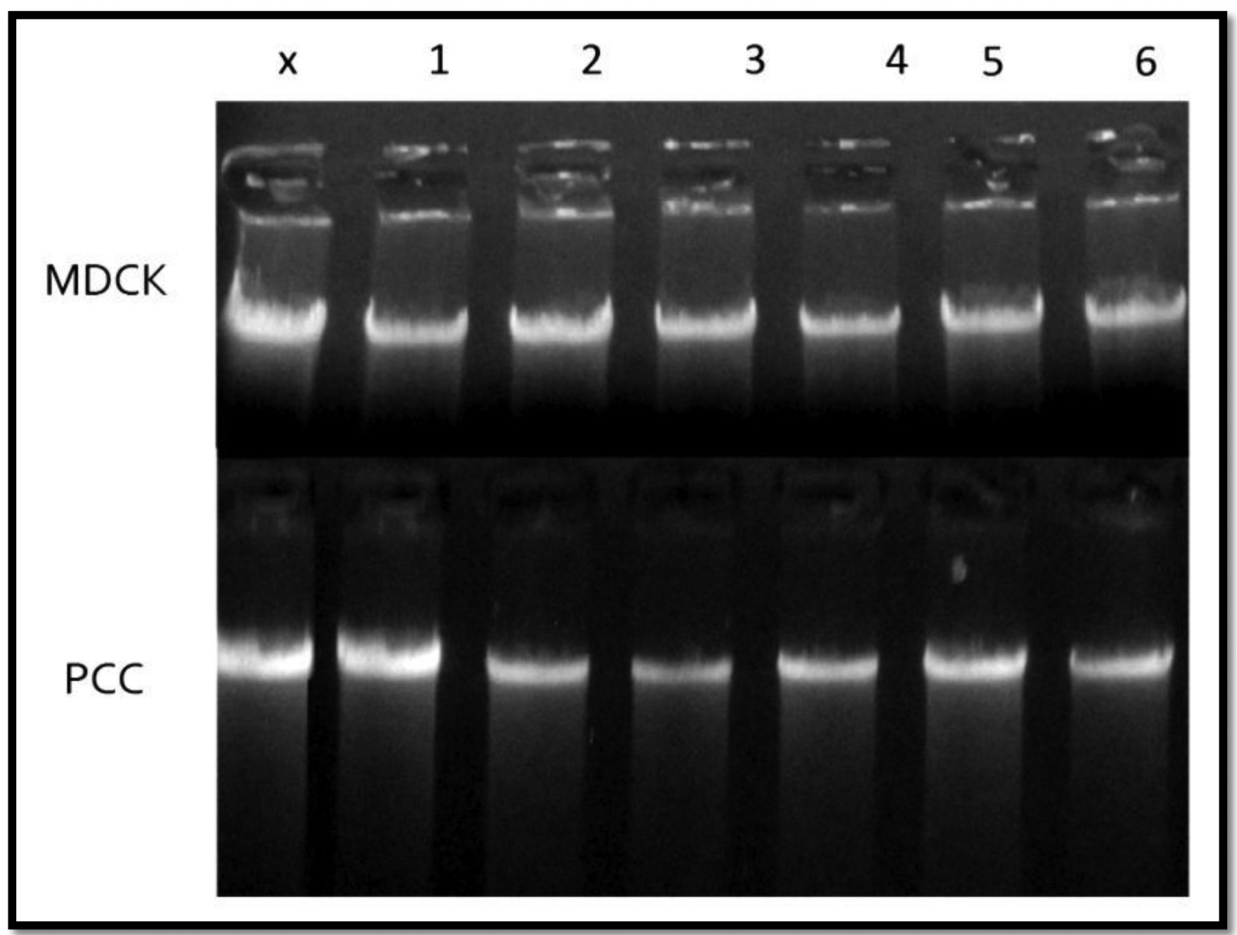

5-р зураг. 100 мкг/мл хандуудаар үйлчилсэн эсүҮдээс ялгасан ДНХ-г 1\%-ийн агароз гельд гүйлгэсэн элекртофореграммын зураг. Х-хяналт, 1- A.хегорhytica этанол ханд, 2- A.хегорhytica 70\%-ийн метанол ханд, 3-A.intricate этанол ханд, 4-A.intricate 70\%-ийн метанол ханд, 5-A.lavandulaefolia этанол ханд, 6-A.lavandulaefolia метанол ханд.

Генийн экспрессийн шинжилгээний дүн

ДНХ-ийн фрагментацийн шинжилгээний буюу апоптозын шинжилгээгээр бүх ханд хавдрын эсүүдийн өөрөө өөрийгөө үхүүлэх процессд нөлөөгүй гэсэн дүн гарсан(5-р зураг) нь апоптози дарангуйлагч уургуудаар дарангуйлагдсан байх боломжтой гэдгийг харуулж байж магадгүй. Тиймээс бид апоптози дарангуйлагч уураг кодлогч bcl-2 ген экспресслэгдэж буй эсэхийг RT-PCR-ийн аргаар судласан юм.
Эерэг хяналт болгож GAPDH генийг авсан. Шинжилгээний дүнд 6 хандаар үйлчилсэн MDCK эсэд bcl-2 генийн MPHX нийлэгжиж буйг илрүүлсэн. Харин РСС эсийг 6 хандаар үйлчилэхэд A.intricate этанол ханд bcl-2 генийн мРНХ нийлэгжихийг саатуулсан ба бусад тохиолдолд уг генийн экспресс илэрсэн (6-р зураг). Энэ шинжилгээнд зөвхөн тухайн генийн мРНХ-ийг илрүүлсэн бөгөөд уургийг шалгаагүй гэдгийг дурьдах нь зүйтэй гэж үзэж байна. 

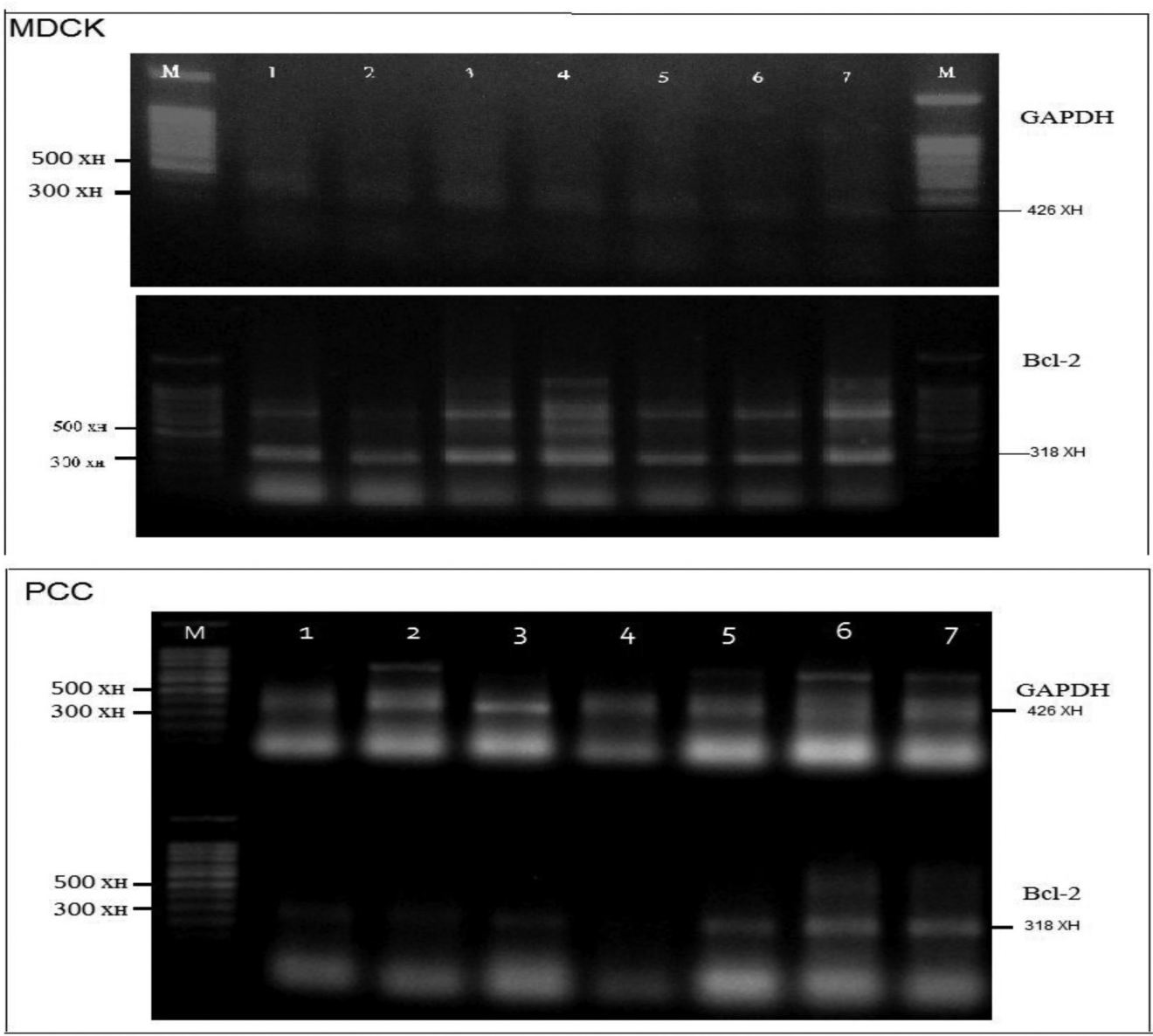

6-p зураг. RT-PCR-ийн бүтээгдэхүүнийг 1\%-ийн агарозын гельд гүйлгэсэн зураг. M-100 хн маркер, 1-7 - 100 мкг/мл хандаар үйлчилсэн эсүүд дэх генийн экспресс. (1- хяналт, 2 - A.xerophytica этанол ханд, 3- A.xerophytica 70\%-ийн метанол ханд, 4- A.intricate этанол ханд, 5- A.intricate 70\%-ийн метанол ханд, 6-A.lavandulaefolia этанол ханд, 7-A.lavandulaefolia метанол ханд.

\section{ХЭЛЦЭМЖ}

Бид өөрсдийн судалгаанд Монгол орны байгаль цаг уурын гурван өөр бүсээс цуглуулсан гурван зүйл шарилжны (A.xerophytica, A.intricata, A.lavandulaefolia) этанол болон метанол хандуудын бөөр (MDCK), элэгний (РССэ зүйл шарилжуудыг урд өмнө нь хавдрын эс дээр судалсан дүн үгүй юм. Энэ судалгаагаар ханд тус бүрийн 2 төрлийн эсийн өсгөвөрийн хуваагдлыг $50 \%$ саатуулах концентрацийг тогтоосон. Өмнө MDCK эс дээр хийсэн судалгаагаар
A. caruifolia шарилжны метанол ханд эсийн $\quad$ хуваагдлыг $50 \%$ дарангуйлах концентраци нь 22 мкг/мл байсан бөгөөд маш хүчтэй үйлчилгээ үзүүлсэн байна [15]. Бидний судалгаагаар A.xerophytica ургамлын этонол (30.61 мкг/мл), метанол (232.9 мкг/мл) ба A.intricata-ийн этонол (76.78 мкг/мл), метанол (313.6 мкг/мл) хандууд MDCK эсийн хуваагдлыг 50\% саатуулах концентраци харьцангуй бага байгаагаас үзэхэд эдгээр хандууд MDCK $-11-$ 
эсийн хуваагдлыг бана концентрацидаа ч саатуулах үйлдэлтэй болох нь ажиглагдаж байна. Эсрэгээрээ A.lavandulaefolia ургамлын этанол (4551 мкг/мл), метанол (3765 мкг/мл) хандууд уг эсийн хуваагдалд сөрөг нөлөө үзүүлэхгүй байна.

Зарим эрдэмтэд өөр 5 зүйл шарилжны (A.kulbadica, A.sieberi, A.turanica, A.santolina, A.diffusa) этанол хандны элэгний хавдрын шугаман эсүүд болох HepG2 ба Нер2 эсүүдэд үзүүлэх нөлөөг судалж[16] уг ханд хавдрын эсийн өсөлт, хуваагдалд сөрөг нөлөө үзүүлж байгааг тогтоожээ. Бидний дүнгээр A.xerophytica этанол (295.4 мкг/мл), метанол (552.6 мкг/мл), A.intricata этанол (416.3 мкг/мл), метанол (33.4 мкг/ мл) ба A.lavandulaefolia этанол (489.5 мкг/ мл), A.lavandulaefolia метанол (156.9 мкг/мл) хандууд бүгд элэгний хавдрын эсийн хуваагдлыг мөн адил конентрациас хамааралтайгаар саатуулах үйлчилгээтэй болохыг тогтоов.

Хавдрын үсэрхийлэх шинж чанарыг in vitro нөхцөлд эсийн өсгөвөрийн шилжин ургах чадвараар төлөөлүүлэн судалдаг. Ийм учир бид эдгээр хандны MDCK, PCC эсүүдийн шилжин ургах чадварт хэрхэн нөлөө үзүүлж буйг шарх нөхөх аргаар шинжилсэн. Бидний судалгааны дүнд хяналтын эсүүдтэй харьцуулахад MDCK эсийн шилжин ургах чадварыг шарилж тус бүрийн метанол хандууд этанол ханднаасаа илүү саатуулах үйлчилгээ үзүүлсэн. Энэ нь хавдрын эсэд (эсийн хуваагдал, шилжин ургах) сөргөөр нөлөөлдөг ургамлын нэгдлүүд нь метанолд хандлагддаг байж

\section{ДУГНЭЛТ}

Энэхүү судалгааны ажлын үр дүнд үндэслэж дараах дүгнэлтүүдийг хийв.

Үүнд:

1. A.xerophytica, A.intricata 2 зүйл ургамлын этанол болон метанол хандууд хавдрын MDCK, РСС эсийн хуваагдалд концентрациас хамааран саатуулах нөлөөтэй байна. болохыг харуулна. РСС эсийн шилжин ургах чадварт A.xerophytica ургамлын этанол (35.4\%), метанол (24\%) ба A.intricata ургамлын этанол (30\%), метанол $(54,2 \%)$ хандууд хяналттай харьцуулахад нэлээн өндөр хувиар саатуулах нөлөө үзүүлсэн бол A.lavandulaefolia ургамлын этанол $(6,7 \%)$, метанол $(7,8 \%)$ ханд бага нөлөөтэй болох нь ажиглагдав.

Апоптозын процессыг илрүүлэх олон арга зүй байдаг. Бид судалгаандаа хэрэглэхэд хялбар энгийн арга зүй болох ДНХ-н (DNA ladder assay) хэсэгчилсэн хэрчим буюу фрагментаци үүсэж буй эсэхийг шинжлэх замаар апоптозын процессыг илрүүлэхийг зорьсон. Шинжилгээний дүнд 6 төрлийн хаын үүсгэсэн байдал илрээгүй. Мөн апоптози дарангуйлагч уураг болох bcl-2 генийн экспрессийг RT-PCR-ийн аргаaр шалгасан. A.intricate этанол хандаар үйлчилсэн PCC эсүүдэд bcl-2 генийн мРНХ илэрсэнгүйь өөрөө хэлбэл уг ханд bcl-2 генийн экспрессд саатуулах нөлөө үзүүлж байна. Харин уг хандаар үйлчлэхэд апоптозын процесс идвэхжихгүй байгаa нь bcl-2 уургаaс хамааралгүй юм. Учир нь bcl-2-оос өөр уургаар апоптози дарангуйлагдсан байх боломжтой. Эсэд апоптозын процессыг дарангуйлах Bclийн бүл уураг байдаг $[17,18]$. Харин бусад туршилтанд хандаар үйлчилсэн MDCK ба РCC эсүүдэд Bcl-2 генийн мРНХ үүсэж байв. Энэ нь уг генийн экспрессийн дүнд MDCK болон PCC эсүүдэд апоптозын процесс саатаж байх боломжтойг харуулж байгаа юм.

2. A. lavandulaefolia ургамлын этанол болон метанол хандууд нь зөвхөн РСС эсийн хуваагдлыг концентрациас хамаарч саатуулах үйлчилгээтэй.

3. A.xerophytica, A.intricata, A.lavandulaefolia зүйл шарилжны бүх этанол, метанол хандууд MDCK, РСC эсүүдийн шилжин ургах чадварыг саатуулж 
байна.

4. Шарилжны төрлийн A.xerophytica, A.intricata, A.lavandulaefolia зүйл ургамлын этанол, метанол хандууд нь хавдрын эсийн Bcl-2-оосхамааралтайапоптозынпроцессыг өдөөхгүй байна. Эдгээр хандуудын эсийн хуваагдал, шилжин ургах чадварт үзүүлж буй сөрөг нөлөө нь апоптозын процессоос хамааралгүй болно.

\section{Ашигласан бүтээлийн жагсаалт}

1. Wendy H, Liang L. The Role of Traditional Chinese Herbal Medicines in Cancer Therapy - from TCM Theory to Mechanistic Insights. Planta Medica 76, (2010): 1118-1131.

2. Peter B, Bernard L. World cancer report 2008. Published by the International Agency for Research on Cancer, Lyon (2008).

3. Rebecca S, Deepa N, Ahmedin J. Cancer Statistics, 2012. Cancer J. for Clinicians 62, (2), (2012): 220-241.

4. http://www.cancer-center.gov.mn/index.php?coid=3\&cid=3

5. Willcox M. Artemisia Species: From Traditional Medicines to Modern Antimalarials — and Back Again. J. of Alternative and Complementary medicine 15, 2 (2009): 101-109.

6. Mucciaralli M, Maffel M. Introduction of the genus In: Wright CW. ed. Artemisia, Taylor and Francis, London, (2002): 1-50.

7. Дариймаа Ш. Монгольской Нарадной Республике/Систематика, география, экология и хозяйственное значение. Диссертаци (1990).

8. Magna J A, Luis M B, Luis A and Paulina B. The Artemisia L. Genus: A Review of Bioactive Essential Oils. Molecules 17, 3 (2012): 2542-2566.

9. Shaikenov T E, Adekenov S M, Williams R M, Prashad N, Baker F L, Madden T L, Ewman R N. Arglabin-DMA, a plant derived sesquiterpene, inhibits farnesyltransferase. Oncology reports 8,(1), (2001): 173-179.

10. Tim M. Rapid colorimetric assay for cellular growth and survival: Application to proliferation and cytotoxicity assays. J.of Immunological Methods 65, (1983): 55-63.

11. Da-ming Z, Molly B, Francisco G, Jean M F, Jian W, Roungyu Z, Huaguang L and Changping Z. Cactus pear: a natural product in cancer chemoprevention. Nutrition Journal 25, 4 (2005).

12. Maria G L. Cell Migration into a Wounded Area In Vitro. Methods in molecular biology 96 (1999): 177-82.

13. Wyllie A H. Glucocorticoid-induced thymocyte apoptosis is associated with endogenous endonuclease activation. Nature 284, 10 (1980): 555-6.

14. Freeman W M, Walker S J, Vrana K E. Quantitative RT-PCR: pitfalls and potential. BioTechniques 26, (1999):112-22, 124-5.

15. Rajbhandari M, Mentel R, Jha P K, Chaudhary R P, Bhattarai S, Gewali M. B, Karmacharya N, Hipper M and Lindequist U. Antiviral Activity of Some Plants Used in Nepalese Traditional Medicine. Evidence-based complementary and alternative medicine 4,6 (2009):517-22.

16. Seyed A E, Nasser V M, Remisa V and Mohammad B O. The Anticancer Activity of Five Species of Artemisia on Hep2 and HepG2 Cell Lines. Pharmacologyonline 3, (2009) : 327339.

17. Gordon C, Shore and Jean V. Modulating the Bcl-2 Family of Apoptosis Suppressors for Potential Therapeutic Benefit in Cancer. American society of hematology (2005): 226-230.

18. Nika N, Danial "BCL-2 Family Proteins: Critical Checkpoints of Apoptotic Cell Death" Clin Cancer Res 13, 24 (2007): 7254-7263. 


\title{
Anticancer activity of some species of Artemisia genus
}

\author{
Boldbaatar.J, Erdenebaatar.P, Khulan.L, Nomiun.D, Nomin.B, Oyunsuren.Ts \\ Laboratory of Molecular Biology, Institute of Biology, Mongolian academy of sciences \\ boogoo506@yahoo.com
}

\section{Summary}

Cancer is one of human health problems globally. Nowadays number of various cancers' incidents is increasing worldwide, especially in the developing countries. Therefore it is necessary to reveal the causes and create novel methods and ways to prevent and to treat different cancers. By now the problems of curing cancer and finding the cancer factor that that lie behind the cancer development have not been yet solved completely. Although surgery, chemotherapy and radiotherapy are the common choices for cancer treatment but they do not have efficient results. Recently an interest of using natural anti-cancer drugs and supplements, especially made of herbs, has increased and during past two decades research number on this topics have been increased globally.

We studied anticancer effects of ethanol and $70 \%$ methanolic extracts of three Artemisia species (Artemisia xerophytica Krasch, Artemisia lavandulaefolia DC, Artemisia intricata Franch) on in vitro cell cultures of PCC and MDCK.

Based on the results of the research following conclusion were made:

Ethanol and methanol extracts of A.xerophytica, A.intricata have inhibitory effect on PCC and MDCK cancerous cells' proliferation with concentration dependence. Ethanol and methanol extracts of A. lavandulaefolia has inhibitory effect on PCC cells proliferation only with concentration dependence. All ethanol and methanol extracts of A.xerophytica, A.intricata, A.lavandulaefolia hogwood plants inhibit MDCK and PCC cells' migration. Ethanol and methanol extracts of A.xerophytica, A.intricata, A.lavandulaefolia do not trigger apoptotic processes activated by Bcl-2. These extracts' anti-proliferation and anti-migration effects have no relation with apoptotic processes.

Key words: Artemisia, Wormwood, Cancer 